\title{
COMMENTS
}

\section{SALES OF CORPORATE CONTROL AT A PREMIUM: AN ANALYSIS AND SUGGESTED APPROACH}

\section{INTRODUCTION}

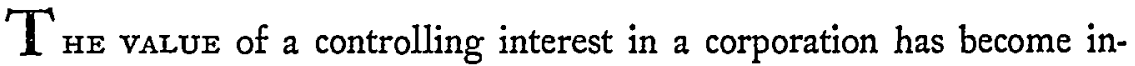
creasingly apparent. Control signifies wealth, prestige, and the power to dictate corporate policy. ${ }^{1}$ In an established corporation the holder of a controlling interest is likely to view the power inherent in his shareholdings as giving his aggregate shares a value above their normal, individual market price. A buyer of such shares, moreover, will frequently be willing to pay a premium to acquire control. However, a minority shareholder, alleging corporate injury or the breach of some duty, may seek to recover a proportionate part of the premium received by the seller. The resulting problem is a complex one, and the courts have not yet evolved a satisfactory approach or arrived at a settled policy. ${ }^{2}$

\section{The Problem and Its Early Judictal Development}

A variety of cases involving sales of corporate control at a premium have been litigated. Numerous inconsistent theories have been employed-often in the same case-resulting in precedent that is "confusing

${ }^{1}$ The concept of corporate control is difficult to delimit. Perhaps the best definition is that of Berle: "Control' may be defined as the capacity to choose directors. As a corollary, it carries capacity to influence the board of directors and possibly to dominate it." Berle, "Control" in Corporate Law, 58 Colum. L. Rev. I2I2 (I958). The nature of control varies greatly with the individual corporation, presenting many difficult legal problems. See Berle \& Means, The Modern Corporation and Private Property 69-1 I8 (1932); Loss, Securities Regulation 8-12 (1951); Berle, supra, at 1213-16; Hornstein, Corporate Control and Private Property Rules, 92 U. PA. L. REV. I, 4-II (1943).

2 For general commentary on the subject see I HORNSTEIN, CoRPORATION LAW AND PRACTICE $\$ 366$ (1959); Berle, supra note I; Hill, The Sale of Controlling Shares, 70 HaRv. L. REv. 986 (x957); Jennings, Trading in Corporate Control, 44 CALIF. I. REv. I (1956); Katz, The Sale of Corporate Control, 38 CH1. BAR REC. 376 (1957); Leech, Transactions in Corporate Control, 104 U. PA. L. REv. 725 (1956). For student comments see 40 CoRNELL L.Q. 786 (1955); 44 IOWA L. REV. 734 (1959); 19 U. CHI. L. Rev. 869 (1952); 40 VA. L. REv. 195 (1954).

This comment does not attempt to deal with questions arising from a sale of all the 
and of questionable utility. Although some authorities have suggested that the proper approach to the problem is to forbid the retention of any premium by the seller, ${ }^{3}$ under the traditional view, absent qualifying factors, the shareholder may dispose of his stock for whatever price it will bring. ${ }^{4}$ However, there is little direct authority upholding such a rule. Indeed, so many modifications have developed that there is no longer a substantial general rule. The large majority of cases have turned on specific abuses of a transfer, resulting in many dicta reiterating the traditional approach and an absence of any ascertainable policy.

In several cases a buyer seeking the corporate assets or a particular corporate asset has been persuaded by the officers to buy instead their controlling stock for the same price. Relying on the general principle that corporate fiduciaries cannot sell a corporate asset for their own benefit, the courts have held the seller liable for the premium, reasoning that, in reality, a corporate asset, and not controlling stock, was sold. ${ }^{5}$ Some commentators, who would deny the seller the right to retain a premium received in a sale of control, have in part relied on these cases to sustain their theory that control is a "corporate asset" which may not be sold by its holder. This "corporate asset" theory has yet to be accepted by the courts. ${ }^{b}$

Some dispute has arisen over whether a seriatim resignation of the directors ${ }^{7}$ following a sale of control at a premium will give rise to

corporate stock in which the controlling shareholders receive more than the minority due to misrepresentation, non-disclosure, or breach of agency. See, e.g., McCord v. Martin, 47 Cal. App. 717, 19x Pac. 89 (1920); Barber v..Martin, 67 Neb. 445, 93 N.W. 722 (1903); Leech, supra at 730-74.

See BERLE \& MEANs, op. cit. supra note $\mathrm{I}$, at 243-44; Gower, Modern CompanY LAW 492, 524 (2d ed. 1957); Berle, supra note I, at 1220-22; cf., Jennings, supra note 2, at 39 ; Leech, sulpra note 2 ; at 815-17.

- For direct authority see Levy v. American Beverage Corp., 265 App. Div. 208, 38 N.Y.S.2d 517 (1942), reversing, Levy v. Feinberg, 29 N.Y.S.2d 550 (Sup. Ct. 194I); Benson v. Braun, 8 Misc. $2 d$ 67, I 55 N.Y.S.2d 622 (Sup. Ct. 1956); Tryon v. Smith, 191 Ore. 172, 229 P.2d 25 I (I951); $c f .$, Nelson v. Northland Life Ins. Co., 197 Minn. 151, 266 N.W. 857 (1936); Keely v. Black, 91 N.J. Eq. 520, III Atl. 22 (1920); Stanton v. Schenck, I40 Misc. 62I, 25 I N.Y. Supp. 221 (Sup. Ct. 193I).

'See Dunnett v. Arn, 7 I F.2d 912 (Ioth Cir. 1934); Horbach v. Coyle, 2 F.2d 702 (8th Cir. 1924); Commonwealth Title Ins. \& Trust Co. v. Seltzer, 227 Pa. 410, 76 Atl. 77 (1910).

- No cases have held that control is a corporate asset. See Hill, supra note 2 at 987. The only decision lending any credence to this theory is Moulton v. Field, 179 Fed. 673 (7th Cir. 1910). Although the plaintiffs in Perlman v. Feldmann, 219 F.2d I73 (2d Cir.), cert. denied, 349 U.S. 952 (1955), argued this theory of liability, the court preferred to rest its decision on other grounds. See Berle, supra note I, at I222.

"In a seriatum resignation, one director resigns at a time with his successor being elected before the next resignation. 
liability. ${ }^{8}$ A solid line of precedent exists forbidding sale of a corporate office when not accompanied by controlling stock. ${ }^{9}$ Some authorities have advocated extension of this corporate office theory of liability to all cases where directors resign incidentally to a stock sale. The proponents of this theory argue that in reality the premium was received in exchange for a corporate office, rendering the seller liable to the corporation for the excess consideration and any losses resulting from looting or mismanagement by the purchasers. The courts have drawn many technical distinctions-none of which are based on sound policyin their efforts to decide each case. For example, several decisions have turned on the question of whether the resignations were bargained for by the parties or were merely incidental to the sale. ${ }^{10}$ However, the "corporate office" theory of liability seems to have fallen into disfavor, and even some proponents of broad liability have rejected it. ${ }^{11}$

Most of the litigation in this area has resulted from claims that corporate assets were wasted as a result of mismanagement or looting by the buyers of control. These cases have involved tangible corporate injury and the seller has often been held liable on theories of fraud or negligence. The serious injuries in these cases have prompted the advocacy of stringent restrictions on sales of control. Berle early suggested that a sale of controlling stock for a premium was in essence a sale of a corporate asset. ${ }^{12} \mathrm{He}$ contended that the ability to dominate property belonging to others is a necessary ingredient of corporateness and that, as a matter of policy, no single individual should profit from its transfer. ${ }^{13}$ In the intervening years $\mathrm{Mr}$. Berle has further analyzed sales of control and refined his original theory. ${ }^{14}$ Although the problem has provoked much discussion among leading commentators, compara-

${ }^{8}$ Compare McClure v. Law, 161 N.Y. 78,55 N.E. 388 (1899) and Porter v. Healy, $244 \mathrm{~Pa} .427$, 91 Atl. 428 (1914) with Levy v. American Beverage Corp., 265 App. Div. 208, 38 N.Y.S.2d 517 (1942) and Benson v. Braun, 8 Misc. 2d 67, 155 N.Y.S.2d 622 (Sup. Ct. 1956).

${ }^{9}$ See, e.g., Forbes v. McDonald, 54 Cal. 98 (1880); Reed v. Catlett, 228 Mo. App. rog, 68 S.W.2d 734 (1934).

${ }^{20}$ See Horbach v. Coyle, 2 F.2d 702 (8th Cir. 1924) ; Porter v. Healy, 244 Pa. 427 , 9I Atl. 428 (1914); Hill, supra note 2, at rooo.

${ }^{21}$ See Benson v. Braun, 8 Misc. 2d 67, 155 N.Y.S.2d 622 (Sup. Ct. 1956). Leech specifically rejects this theory as a poor determinent of liability. Leech, supra note 2 , at 807.

is See BERLE \& MEANS, op. cit. supra note 1 .

${ }^{23} I d$. at 244 .

${ }^{14}$ See Berle, supra note I. See also Berle, Corporate Powers in Trust, 44 Harv. L. REV. 1049 (1931). 
tively few cases have arisen and until 1955 no court had given judicial sanction to any broad prohibitive theory.

\section{The Perlman Decision}

In 1955 the controversial case of Perlman v. Feldmann ${ }^{15}$ focused attention on the problem of sale of control. Feldmann, president and controlling shareholder of a small steel company, sold his stock to a corporation composed of end consumers of steel..$^{16}$ As part of the transaction, he agreed to resign as director and president, to procure resignations of the other directors, and not to participate for a stipulated period in any financing of steel companies. In a derivative action a minority shareholder sought to recover the premium received by Feldmann from his sale of stock.

The District Court found no damage to the corporation and dismissed the action. ${ }^{17}$ The decision, however, was reversed by the Court of Appeals for the Second Circuit, one judge dissenting. ${ }^{18}$ The opinion of the court analogized the transaction to an appropriation of a corporate opportunity, noting that Feldmann had unfairly deprived the corporation of the benefit of "his uncorrupted business judgment."19 The court held that the defendant, as controlling shareholder and director, owed a fiduciary duty to the corporation and to the minority shareholders. More importantly, under the court's conception of corporate injury, the burden was on Feldmann to show that his conduct had not prevented the corporation from exercising opportunities for gain. In remanding the case for determination of damages, the court concluded: "When the sale necessarily results in a sacrifice of this element of corporate good will and consequent unusual profit to the fiduciary who has caused the sacrifices, he shall account for his gains. ${ }^{20}$

\footnotetext{
${ }^{10} 219$ F.2d 173 (2d Cir.), cert. denied, 349 U.S. 952 (1955), reversing, 129 F. Supp. 162 (D. Conn. 1952). See notes in 40 CoRNell L.Q. 786 (1955); 68 HARv. L. REv. I274 (1955); 22 U. CHI. L. REv. 895 (1955); [1956] U. ILL. L.F. I31 (1956). For the fixing of damages, see 154 F. Supp. 436 (D. Conn. 1957), discussed in 71 HARv. L. REv, 1559 (1958).

${ }^{10}$ The sale, was consumated during the Korean War at a time when steel supplies were "tight," and consumers were accordingly willing to pay high to influence the market allocation of steel. 219 F.2d 173, 175. The court felt that the corporation could have perhaps used the period of short supply to better advantage. $I d$. at 177 .

${ }^{27}{ }_{129}$ F. Supp. 162, $185-87$ (D. Conn. 1952).

${ }^{28}$ Judge Swan, dissenting, contended, "[A] majority or dominant shareholder is ordinarily privileged to sell his stock at the best price obtainable from the purchaser. In so doing he acts on his own behalf, not as an agent of the corporation." 2 I9 F,2d I 73,179 .

${ }^{10} I d$, at $176-77$.

${ }^{20} \mathrm{Id}$. at $17 \mathrm{~d}$. The court laid down a broad definition of corporate injury; "Only
} 
Because Perlman imposed on the defendant an almost impossible burden of proof, the decision virtually prohibited retention of a premium by the seller of control. The broad scope of this decision has provoked much disagreement among commentators. ${ }^{21}$

\section{Judicial Developments Since Perlman}

In three recent cases, plaintiffs with marginal claims have sought to posit liability on Perlman. In each of these decisions the court considered and rejected the adoption of an absolute rule denying the seller of control the right to retain the premium realized from the sale.

\section{A. Benson v. Braun}

In the New York case of Benson v. Braun ${ }^{22}$ a minority shareholder sued former controlling shareholders and directors who had sold their stock for a premium and resigned their offces. The court ruled for the defendants, holding that there was no evidence of bargained-for resignations and that "no damage was done to the corporation and no injury was caused to the stockholders or creditors." ${ }^{23}$ The opinion notes that free transferability of controlling shares is economically desirable and that a rule which effectively restricts transfer is unsound. ${ }^{24}$ Rejecting the Perlman policy, the court declined to follow the narrow holding in that case, ruling that the plaintiff had the burden of proof on the issue of injury.

\section{B. SEC v. Insurance Sec., Inc.}

$S E C$ v. Insurance Sec., Inc., ${ }^{25}$ involved an action brought under Section 36 of the Investment Company Act, which authorizes the Securities and Exchange Commission to obtain injunctions against underwriters and advisors of registered companies for "gross misconduct" or

if the defendants had been able to negate completely any possibility of gain by Newport could they have prevailed." $I d$. at I 77. The court further held that Feldmann had the burden of separating the consideration received for control from the value of the stock. Id. at 178 .

${ }^{21}$ See Berle, supra note $\mathrm{r}$, at 1222. Compare Hill, supra note 2, at 986, 1038-39 with Leech, supra note 2, at 815-17.

${ }_{22} 8$ Misc. 2d 67, I55 N.Y.S.2d 622 (Sup. Ct. 1956). For the previous history of this case see 141 N.Y.S.2d 286 (Sup. Ct.), aff'd, 286 App. Div. 1098, 145 N.Y.S.2d 7 II (1955). In these earlier phases the defendant's motion to dismiss was denied, primarily due to an allegation in the complaint that the buyers of control had previously looted the corporation. This allegation was not substantiated at the ensuing trial.

${ }^{23} 8$ Misc. 2d 67, 73, 155 N.Y.S.2d 622, 629 (Sup. Ct. 1956).

24 Id. at 69,155 N.Y.S.2d at 626 .

${ }_{25}^{25} 254$ F.2d 642 (9th Cir.), cert. denied, 358 U.S. 823 (1958), affirming, 146 F. Supp. 778 (N.D. Cal. 1956). 
"gross abuse of trust." The defendant, investment adviser and principal underwriter for a registered investment trust fund that had no officers of its own, transfered his controlling stock for a premium of several million dollars. The SEC, alleging that the seller received the premium for a sale of his position as advisor, sought to enjoin the purchasing group from acting as advisor and to compel an accounting of the premium and investment fees.

The District Court dismissed the action and the Court of Appeals for the Ninth Circuit affirmed. After distinguishing Perlman, ${ }^{27}$ the court held that nothing in general equity principles indicated that the seller's conduct amounted to "gross misconduct" or "gross abuse of trust." Thus, the court rejected an attempt by the SEC to interpolate the prohibitive Perlman rule into the Investment Company Act. Although the court did not speculate as to the propriety of Perlman, it intimated that insofar as SEC jurisdiction is concerned any change in the law governing sales of control must be made by Congress. ${ }^{29}$

\section{Manacher v. Reynolds}

The inost recent judicial rejection of Perlman is found in a 1960 Delaware decision, Manacher $v$. Reynolds. ${ }^{30}$ United States Foil was a holding company owning the controlling stock in Reynolds Metals Company. Foil's own stock was divided into voting ("A") stock held by the Reynolds family and widely-held, nonvoting (" $\mathrm{B}$ ") stock. The "B" stock sold on the market at a one-third discount from what its equity in Reynolds Metals warranted. The original plaintiff had sought a dissolution of Foil and a distribution of its stock in Metals. In a proposed settlement, a reclassification of stock into a single class with equal rights was agreed upon. Each share of "A" was to be ex-

26 "The Commission is authorized to bring an action in the proper district court of the United States . . alleging that a person serving or acting in one or more of the following capacities has been guilty ... of gross misconduct or gross abuse of trust in respect of any registered investment company for which such person so serves or acts:

( 1 ) as officer, director, nember of an advisory board, investment adviser, or depositor; or

(2) as principal underwriter ....

If the Commission's allegations of such gross misconduct or gross abuse of trust are established, the court shall enjoin such persons from acting in such capacity or capacities either permanently or for such period of time as it in its discretion shall deem appropriate." 54 Stat. 841 (1940), 15 U.S.C. \& 80a-35 (1958).

${ }^{22}{ }_{254}$ F.2d 642, 650 (9th Cir. 1958 ).

${ }^{28} I d$, at 651 .

${ }^{20}$ Ibid.

${ }^{30}{ }_{16}$ A.2d 741 (Del. Ch. 1960). 
changed for three shares of new stock and each share of " $B$ " for one share of new stock. Foil would then be dissolved. The settlement and dissolution were ratified by both " $\mathrm{A}$ " and " $\mathrm{B}$ " shareholders, and the market value of " $\mathrm{B}$ " rapidly increased, almost eliminating the discount.

Dissenting " $\mathrm{B}$ " shareholders intervened, however, contending that the settlement was unfair because it gave the " $\mathrm{A}$ " group a premium for giving up absolute control. Their objection was based on Berle's corporate asset theory and the fiduciary principle of Perlman. The chancellor rejected these arguments, pointing out that the " $\mathrm{B}$ " group had obtained the obliteration of the discount which could only have been accomplished by the "A" group's surrender of absolute control. After distinguishing Perlman, he added:" ${ }^{31}$

If this distinction lacks substance, $I$ can only express a preference for the ... view that the increment in stock value belongs to the sellers, absent some breach of duty. I say this because I am satisfied that a practical decision of this issue had been in existence in the business community for too many years for a court to upset it. Moreover, the implications inherent in the adoption of the rule espoused by Mr. Berle would create more doubts than it would resolve.

Although Perlman was easily distinguishable on its facts, the court's approach suggests a basic policy difference. The chancellor, employing a business reality test, permitted the receipt of a premium for surrender of absolute control and approved the settlement as fair to all shareholders.

As evidenced by the latest judicial pronouncements, Perlman has not settled this confused area of the law. These decisions point to a shift in emphasis toward a more pragmatic approach.

\section{Analysis and Reappraisal}

The frequent abuses that have accompanied sale of control have prompted the advocation of a broad rule of accountability for any premium realized on such a sale. It is suggested, however, that this problem should be approached more analytically, on a case by case basis. Under such an approach, the court would first determine if the seller's negligence or bad faith conduct resulted in injury to the corporation. If so, liability should be squarely based on the wrongfulness of the conduct. If the seller was not culpable, the court would determine if the circumstances surrounding the sale should cause the seller of control

\footnotetext{
${ }^{31} I d$. at $75 \mathrm{x}$.
} 
to be held strictly liable for the premium realized on the sale. The shareholders' reasonable economic expectations should be the court's primary guide in each decision. The court should scrutinize the control pattern of the particular corporation involved and attempt to ascertain the reasonable expectations of the shareholders toward participation in control. These expectations will vary according to the corporation's control pattern.

\section{A. Control Patterns and Expectations as a Test of Strict Liability for Sale of Control}

\section{The Public-Issue Corporation}

Stock in public-issue corporations generally is widely held; as a result, no single stockholder is able to obtain control through his holdings. Control is frequently maintained by professional management, which usually perpetuates itself in office. ${ }^{32}$ Stockholders in these corporations normally purchase their shares solely for investment and not in anticipation of participating in management. Their only expectation is that their investment will be protected and yield a fair return..$^{33}$ Because stock transactions and management changes have little or no interdependency, cases involving sales of controlling stock have not arisen.

\section{The Close Corporation}

The control pattern of a close corporation differs markedly from that of its public-issue counterpart and in many respects deviates from the statutory norm of director control. Frequently, all shareholders expect to participate in the management of the close corporation as if the enterprise were a partnership. ${ }^{34}$ This control pattern may be set by'

\footnotetext{
${ }^{32}$ See, e.g., Berle \& Means, The Modern Corporation and Private Property 84-90, I24 (1932); Hornstein, Corporate Control and Private Property Rules, $92 U$. PA. L. Rev. I, 7-8 (1943).

The individuals comprising management change through the use of pension plans and other retirement devices. Thus management is able to perpetuate control and still have directors and officers with an interest in the business. These "turnover mechanisms" serve an economic function similar to that of the premium in "mixed" corporations.

${ }^{33}$ BERLE \& MEANs, op. cit. supra note 32 , at 63-68.

36 "[S] hareholders in a close corporation are usually vitally interested in maintaining their proportionate interest in dividends and assets . . . Control is more important to a shareholder in a closley held corporation than to one in a publicly held corporation because control in a closely held corporation often means employment, and the loss of control may result in a termination of employment." I O'NEAL, CLOSE CORPORATIONS: LAW AND PRACTICE 120-21 (1958). See I HornsteIn, CORPoration LaW and PraCTICE \& 172 (1959); Hornstein, Judicial Tolerance of the Incorporated Partnership, I 8 LAW \& CONTEMP. PROB. 435, 439-4I (1953).
} 
special charter and by-law provisions or developed through other agreements and business practices. ${ }^{35}$ In a sense control belongs to all, and an unrestricted, unilateral power to dispose of it may upset the delicate basis upon which the quasi-partners have established their business. When a sale occurs the remaining shareholders are extremely susceptible to injury through squeeze-outs and other corporate manipulations. $^{36}$ Difficulties stemming from the sale of control in a close corporation may usually be prevented through careful drafting of charter and by-law provisions and shareholder agreements. Provisions allowing the corporation or the remaining shareholders a first option on the purchase of shares and buy and sell arrangements among shareholders are often effectively utilized to prevent sales to outsiders. ${ }^{37}$ However, incomplete drafting or local policy against such restraints on sale may give a controlling shareholder an unrestricted power to sell to outsiders, to the detriment of the business expectations of the remaining participants. ${ }^{38}$ Where there has been a sale of control in a close corporation, a court should carefully analyze the business arrangement and determine the reasonable expectations of the parties. If the business practices of the

\footnotetext{
${ }^{35}$ See generally, I HoRnstein, CoRporation LaW and Practice $\$ \S$ 171-85 (1959); I O'Neal, Close Corporations: LaW aNd Practice $\$ \S 5.01-5.39$ (1958); O'Neal, Giving Shareholders Power to Veto Corporate Decisions: Use of Special Charter and By-law Provisions, I8 LAW \& CONTEMP. Prob. 45 I (1953); Steadman, Maintaining Control of Close Corporations, 14 Bus. LAw. 1077 (1959).

${ }^{38}$ See 2 O'NEAL, ClOSE CORPorations: LAW AND PRACTICE $\$ \S 8.07-8.09$ (1958). A typical situation is that involved in the Inland Steel litigation. See Lebold v. Inland S.S. Co., 82 F.2d 35 I (7th Cir. I936) and Lebold v. Inland Steel Co., 125 F.2d 369 (7th Cir. 1942). For an excellent treatment of squeeze-outs, see generally, O'NEAL \& DERWIN, EXPULSION OR OPPRESSION OF BUSINESS ASSOCIATES: "SQUEEZE-OUTS" IN SMALI ENTERPRISES (I961).

${ }^{37}$ See Hornstein, Judical Tolerance of the Incorporated Partnership, I8 LAW \& Contemp. Prob. 435, 445-48 (1953). See generally, Cataldo, Stock Transfer Restrictions and the Closed Corporation, 37 VA. L. REv. 229 (1951); O'Neal, Restrictions on Transfer of Stock in Closely Held Corporations: Planning and Drafting, 65 HARv. L. REv. 773 (1952).

${ }^{38}$ See O'Neal, supra note 37 , at 774. A case instructively illustrating such frustration is United Trust Ltd. v. South African Milling Co., [1959] 2 So. Afr. L.R. 426. There, plaintiff milling company organized a bakery as a consumer of its product. Plaintiff later sold some stock to one of the bakery's managers, and they jointly over a period of years sold stock to officers of the company. Although a complex control pattern was expressly provided for by shareholder agreements, the restrictions on alienation of the shares were subject to suspension by a vote of the majority of the shares. A group of the shareholders, obtaining fifty-one per cent of the stock, sold out as a block to defendant milling company who was the plaintiff's major competitor. The plaintiff's action for injunction and recission was unsuccessful. Careful drafting would have avoided this result. The case was criticized in 76 S.A.L.J. 259 (1959).
} 
corporation in question indicate that the participating shareholders intended that control was to be shared through management participation, one shareholder should not be permitted to profit from his unilateral disruption of the arrangement. As one authority who has extensively studied the field of close corporations points out: ${ }^{39}$

Where several owners carry on an enterprise together. . . . their relation should be a fiduciary one similar to the relationship among partners. The fact that the enterprise is incorporated should not substantially change the picture. ... [W] [Wen businessmen organize a corporation they enter into their relationship against a background of corporate statutes and common law doctrine which vests in the directors the power to manage the corporation's affairs.... That should not mean, however, that the directors or the majority shareholders should be permitted to exercise their powers arbitrarily or without regard to the legitimate expectations of the minority shareholders.

When the court has determined that a sale violates the reasonable expectations of the remaining shareholders, the problem of a proper remedy must be considered. Absent express restriction on sale, a shareholder normally has the right to dispose of his stock. Thus, prospective relief by injunction is normally limited to cases involving violations of shareholder agreements or forseeable injury to the corporation. ${ }^{40}$ However, recovery of the premium should be permitted since the proceeds of a sale of control, in reality, belong to all the participants when the sale is contrary to their reasonable expectations. ${ }^{41}$ Although the judicial remedy of recovery of the premium is helpful relief, the best solution

${ }^{30} 2$ O'Neal, op. cit. supra note 36 , at 107-08. Cf., Mr. Justice Brandeis in Southern Pacific Co. v. Bogert, 250 U.S. $483,487-88$ (Igrg). "The majority has the right to control; but when it does so, it occupies a fiduciary relation toward the minority ...."

${ }^{10}$ See Nelson v. Northland Life Ins. Co., 197 Minn. I5I, 266 N.W. 857 (1936) (recission denied); Ingraham v. National Salt Co., 36 Misc. 646, 74 N.Y. Supp. 388 (Sup. Ct.), aff'd per curiam, 72 App. Div. 582, 76 N.Y. Supp. 1016 (1902), aff'd per curiam, I79 N.Y. 556, 7I N.E. II3 (1904); Phelan v. Edison Elec. Illuminating Co., 24 Misc. I09, 53 N.Y. Supp. 305 (Sup. Ct. I8g8) ; cf., HorNste1N, op. cit. supra note 35 , at $\S \mathrm{r} 86$; O'NEAL, op. cit. supra note 36 , at $\$ 7.14$; Steadman, supra note 35 , at rogo.

${ }^{4 S}$ See Sautter v. Fulmer, 258 N.Y. 107, 179 N.E. 3 10 (1932).

Occasionally the "law of self-help" may be effectively used. in one case, $A$ and $B$ held the majority of stock in a close corporation, but were a minority on a five-man board of directors. They contracted to sell their shares to an outsider at a high price. $C, D$ and $E$, the remaining shareholder-directors, voted to issue enough shares to $E$ to eradicate the $A-B$ majority. $E$ testified that this was done to perpetuate the company on the same basis as it had been set up. The court, in permitting the issue of stock, held that this was not fraud but was for a corporate purpose. Standard International Corp. v. McDonald Printing Co., I59 N.E.2d 822 (Ohio C.P. 1959). 
to the problem is through a perceptive use of preventive drafting designed to effectuate shareholder expectations.

\section{The "Mixed" Corporation}

Many corporations combine features of both the public-issue and the close corporation in their control pattern; one or a small group of shareholders has stock control, and the remainder of the outstanding shares are widely-held. Buy-out provisions are impractical since the widelyheld stock should remain unfettered by restraints on sale. In these businesses, conveniently denominated "mixed" corporations, the problem of sale of control at a premium most frequently arises.

It is evident from an examination of the control pattern of a "mixed" corporation that the economic expectations of individual shareholders will vary. ${ }^{42}$ The widely-held stock, as in the public-issue corporation, is purchased primarily, if not solely, for investment and its owners may accurately be termed investment shareholders. On the other hand, the controlling shareholder in a "mixed" corporation holds his stock primarily to effectuate control and to manage the business. He realistically expects to receive a premium upon sale of the controlling stock based on the recognized separate worth of the control element as an increment to the investment value of the stock. ${ }^{43}$ Often the controlling shareholder has purchased control at a premium or amassed it through the market and buyers are willing to pay for this aggregate value as an asset. Clearly, it is reasonable for the controlling shareholder to expect to manage the business and to receive value for the control upon sale of his stock. ${ }^{44}$ Absent actual abuse, positive considerations support a realization of the shareholder's expectations.

When several shareholders participate in management of a "mixed" corporation, a situation similar to that of the close corporation is presented. The court should investigate the particular control pattern and

\footnotetext{
42 See Baker \& Cary, Cases on Corporations, 331 (3rd ed. 1958). Illustrative of "mixed" corporations are Ford Motor Company and Reynolds Metals. See also, Perlman v. Feldmann 129 F. Supp. 162,184 (D. Conn. 1952); Barnes v. Brown, 8o N.Y. 527 (1880); Katz, The Sale of Corporate Control, 38 CHI. BAR REc. $376,{ }_{3} 80$ (x957).

${ }^{43}$ See Stanton v. Schenck, 140 Misc. 62x, 633, 25x N.Y. Supp. 22x, 233 (Sup. Ct. $\mathrm{x} 93 \mathrm{x}$ ), where the court said, "No one will argue that the holder of a large block of the stock of a corporation would be under a duty to account for his profit to the corporation. As such holder he might be in a position to command a considerable premium above current prices in a favorable market. The advantage would be entirely his ...." See Tryon v. Smith, 19x Ore. 172, 180, 229 P.2d 251, 254 (1951).

"See Short v. Treasury Comm'rs, [1948] A.C. 534, 546; Hornstein, Corporate Control and Private Property Rules, 92 U. PA. L. REv. 1, 4 (1943).
} 
the expectations of the participating shareholders in determining whether a unilateral disruption of the corporate organization should subject the seller to liability. Controlling shareholders of a "mixed" corporation are also quasi-partners and should be subject to a mutual fiduciary duty on control dispositions. ${ }^{45}$ However, this principle should not extend to the relationship between controlling and investment shareholders, who have no such identiy of interests. ${ }^{46}$ Since an investment shareholder does not expect to participate in management when he purchases his stock, his expectations are not prejudiced by a transfer of control, and he should not share in the premium.

Another positive reason for permitting the seller of controlling stock in a "mixed" corporation to retain his premium is the useful economic function the premium serves. If the shareholder desires to leave the business, the receipt of a premium will facilitate his exit, and control may thus pass from a party who has lost interest in active management to one who has such an interest. ${ }^{47}$ The change should be complete, including stock and directors; there should be no liability posited on the theory of sale of a corporate office. ${ }^{48}$

\footnotetext{
${ }^{45}$ As in the close corporation, the utility of various restrictions on alienation of shares among such control groups should not be overlooked.

${ }^{4}$ See Hill, The Sale of Controlling Shares, 70 HARv. L. REv. 986, 1013-20 (1957); Katz, supra note 42, at 380 ; cf., Keely v. Black, 91 N.J. Eq. 520, II Atl. 22 (1920); Tryon v. Smith, I91 Ore. 172, 229 P.2d 25 I (1954).

"See Nelson v. Northland Life Ins. Co., 197 Minn. 151, 266 N.W. 857 (1936); Hill, supra note 46 , at IoI7-I8; Katz, supra note 42 , at 379 ; Comment, I9 U. CHI. L. REv. 869, 87 (1952); cf., Beitman v. Steiner, 98 Ala. 241, 13 So. 87 (1893).

Some writers have intimated that the seller of control should insist as a condition to the sale that a prospective buyer offer to purchase all the outstanding shares at the same price. This requirement is said to protect the investment shareholders and to correlate with Perlman. Jennings, Trading in Corporate Control, 44 CALIF. L. REv. I, 39 (1956). As a device for protecting investment shareholders such a requirement defeats its own purpose. Often there will be no sale if a general offer is required, and the controlling shareholder may thus be forced to sell on the market or remain locked in the business. Any large volume of stock on the market may bring the exchange value down, impairing the investment value of the stock and injurying the investment shareholders. In effect, a scheme serving a useful function in many close corporations may seriously injure shareholders in a "mixed" corporation. Cf., Katz, supra note 42, at 379-80.

${ }^{48}$ This policy determination was cogently pointed out in one of the more recent cases. "The purpose of the rules restricting transfers of controlling interests is to prevent transactions tainted with bad faith, intent to defraud or negligence on the part of those possessing control. In the absence of such elements it is desirable that control of a corporation be readily transferable so that persons with ideas for improving a business might be able to put their ability to work. [citation omitted] When ownership of controlling stock changes hands, a change in the board of directors is generally
} 
The premium promotes changes in control, reducing the likelihood of stagnation in the business; at the same time no one buying or holding control will fear being locked in a business due to stifling restraints on the transfer of stock. A rule of law resulting in a virtual prohibition of sale at a premium has the practical effect of restricting the free transferability of controlling stock contrary to sound economic policy.

A prohibition on sale of control at a premium fails to accord with the expectations of the shareholders in a "mixed" corporation. Control has value to its holder who anticipates receiving consideration for its sale; investment shareholders expect their investment to be protected and not to participate in control. However, transfers of control are susceptible of abuse. While these abuses have led some writers to advocate an absolute prohibition of the retention of a premium for control, the decided cases indicate that other adequate remedies for these abuses are available.

\section{B. Remedies for Corporate Injury Resulting from}

\section{Control Transfers}

The courts have utilized several traditional theories to provide remedies for serious injuries to a corporation resulting from a transfer of controlling stock. The most common of these injuries is a wasting of corporate assets by the new holder of control through actual looting or management ineptness. The law governing the wasting of corporate assets is comparatively settled; the shareholder who sells control is held to a duty of due care and diligence. ${ }^{40}$ If the sale results in injury to the corporation he may be liable for negligence. ${ }^{50}$

expected." Benson v. Braun, 8 Misc. 2d 67, 69, 155 N.Y.S.2d 622, 625 (Sup. Ct. 1956). See Farmers Loan \& Trust Co. v. New York \& No. R.R., 150 N.Y. 410, 425, 44 N.E. 1043, 1046 (1896); Barnes v. Brown, 80 N.Y. 527 (1880).

${ }^{4}$ See Insuranshares Corp. v. Northern Fiscal Corp., 35 F. Supp. 22 (E.D. Pa. 1940); Field v. Western Life Indem. Co., I66 Fed. 607 (N.D. Ill. 1908), aff'd stıb nom., Moulton v. Field, 179 Fed. 673 (7th Cir. 1910); Gerdes v. Reynolds, 28 N.Y.S.2d 622 (Sup. Ct. I 941 ).

${ }^{80}$ When the court is inclined to allow recovery from the seller, additional problems arise in determining the amount and the recipient of the award. A recovery by the corporation, unless it is in receivership, will effectively return to the buyers their payment. Most courts have awarded pro rata recovery to the minority sharcholders. See Perlman v. Feldmann, 219 F.2d 173 (2d Cir. 1955); Dunnett v. Arn, 71 F.2d 912 (roth Cir. 1934); Porter v. Healy, 244 Pa. 427, 91 Atl. 428 (1914). Several cases have permitted a receiver of the corporation to recover. McClure v. Law, 161 N.Y. 78, 55 N.E. 388 (1889); Ballentine v. Ferretti, 28 N.Y.S.2d 668 (Supt. Ct. 194 I) Gerdes v. Reynolds, 28 N.Y.S.2d 622 (Sup. Ct. 1941); Dale v. Thomas H. Temple Co., 186 Tenn. 69, 208 S.W.2d 344 (1948). Berle favors recovery by the corporations 
When certain "special facts" are present the seller is deemed to be on notice and is required to make a diligent inquiry into the background of the buyers. Although the courts have not formulated a general rule setting out what "special facts" precipitate notice, the decided cases give some indication of important factors to be considered. In several cases involving predominately liquid corporate assets, such as securities, the courts have imposed a duty to investigate. ${ }^{52}$ In accord with business reality, these courts have indicated that one is negligent if, without inquiry, he places easily convertible assets in the hands of a stranger. In addition, the offer of a large premium alone may call for investigation..$^{53}$

The seller should carefully examine the background of the buyer if under all the circumstances such an investigation would be prudent to protect the minority's investment. ${ }^{54}$ A succint statement of the rule is found in the leading case of Insuranshares Corp. v. Northern Fiscal Corp.: 55

[T] he owners of control are under a duty not to transfer it to outsiders if the circumstances surrounding the proposed transfer are such as to awaken suspicion and put a prudent man on his guard. ... If, after ... investigation, the sellers are deceived by false representations, there might not be liability, but if the circumstances put the seller on notice and if no adequate investigation is made and harm follows, then liability also follows.

under any circumstances. See Berle, Control in Corporate Law, 58 Colum. L. Rev. 1212,1220 (1958).

In awarding damages, the courts, with little consistency, have sometimes measured recovery by the extent of the injury to the corporation; sometimes by the premium; and sometimes by both. See e.g., Insuranshares Corp. v. Northern Fiscal Corp., supra note 49 (loss to the corporation); Ballentine v. Ferretti, supra (premium only); Gerdes v. Reynolds, supra (both); Dale v. Thomas H. Temple Co., supra (most of loss to corporation).

"The "special facts" doctrine developed in connection with the analogous problem where the corporate insider buys stock from a minority shareholder without full disclosure of inside information bearing on the value. See Strong v. Repide, 2 I $_{3}$ U.S. 4 I 9 (1909). See analysis in Stickells, Stockholders' Duty in Sale of Stock, 3 I B.U.L. REV. I91 (1951).

${ }^{62}$ See Insuranshares Corp. v. Northern Fiscal Corp., 35 F. Supp. 22 (E.D. Pa. 1940); Ballentine v. Ferretti, 28 N.Y.S.2d 668 (Sup. Ct. 1941); Gerdes v. Reynolds, 28 N.Y.S.2d 622 (Sup. Ct. 1941).

${ }^{83}$ See Insuranshares Corp. v. Northern Fiscal Corp., supra note 51; Gerdes v. Reynolds, supra note 52 .

"See Benson v. Braun, 14I N.Y.S.2d 286 (Sup. Ct. 1955) (see note 22 supra). Also, if the prospective buyers have a reputation for looting or mismanagement in the business community, the seller will be liable. See Field v. Western Life Indem. Co., 166 Fed. 607 (N.D. Ill. 1908).

${ }^{85} 35$ F. Supp. 22, 25 (E.D. Pa. 1940). 
Occasionally a court will hold the seller liable for fraud in the sale. For example, where the contract of sale called for deferred payment of the purchase price and it appeared that payment would come out of the corporate assets, the seller was held liable for the loss.58 Also, when the seller refused an offer for the sale of a particular corporate asset and later sold controlling stock to the same buyer at the same price, one court, looking to the substance of the transaction, permitted recovery for fraud in selling a corporate asset for personal benefit..57

Although the theory of liability upon which a court reaches its result is often difficult to ascertain, ${ }^{58}$ the fraud and negligence grounds are well established. These remedies provide adequate relief for serious abuses; ${ }^{59}$ yet, a prudent seller of control, acting in good faith, is free to realize his reasonable expectations.

\section{ConcLusion}

Transfers of corporate control for a premium present the courts with many intricate problems which should be settled through a pragmatic approach. A court, by carefully examining the control pattern of the corporation, should ascertain the reasonable expectations of the shareholders. In conjunction with traditional remedies of fraud and negligence, the fiduciary concept should be utilized in the appropriate case to protect these shareholder expectations. However, any further imposition of liability is unwarranted and contrary to business reality and sound economic policy.

\footnotetext{
${ }^{56}$ Dale v. Thomas H. Temple Co., 186 Tenn. 69, 208 S.W.2d 344 (1948); of., Upton v. Southern Produce Co., 147 Va. 937, 133 S.E. 576 (1926).

${ }^{87}$ Commonwealth Title Ins. \& Trust Co. v. Seltzer, 227 Pa. 410, 76 Atl. 77 (1910); cf., Dunnett v. Arn, 71 F.2d 912 (1oth Cir. 1934); Horbach v. Coyle, 2 F.2d 702 (8th Cir. 1924).

${ }^{88}$ See Oil Shares, Inc. v. Kahn, 94 F.2d 751 (3rd Cir. 1938); Moulton v. Field, 179 Fed. 673 (7th Cir. 1910); Gerdes v. Reynolds, 28 N.Y.S.2d 622 (Sup. Ct. 1941). See also Seagrave Corp. v. Mount, 212 F.2d 389 (6th Cir. 1954).

${ }^{89}$ See Hill, supra note 46 , at 1039.
} 